\title{
Retrospective Study of Traumatic Dental Injuries of Patients Treated at a Dental Trauma Clinic in Santiago, Chile
}

\author{
Estudio retrospectivo de Casos Atendidos en Clínica de \\ Traumatología Dentoalveolar en Santiago, Chile
}

\author{
Andrea Véliz'-2; Braulio Catalán"2,3; Carlos Rioseco $2-4$; Pilar Jerez ${ }^{2-4}$; \\ André Latapiat ${ }^{1-2}$; Diego Matamoros ${ }^{2}$; Camila Corral2,5
}

VÉLIZ, A.; CATALÁN, B.; RIOSECO, C.; JEREZ, P.; LATAPIAT, A.; MATAMOROS, D. \& CORRAL, C. Retrospective study of traumatic dental injuries of patients treated at a dental trauma clinic in Santiago, Chile. Int. J. Odontostomat., 11(4):405410, 2017.

ABSTRACT: The aim of this study was to carry out a retrospective study of cases seen at the Child and Adult Dental Traumatology Clinic, Faculty of Dentistry, Universidad de Chile, Santiago. A retrospective study was carried out analysing the records of patients seen at the Dental Traumatology Clinic, Faculty of Dentistry, Universidad de Chile from January 2012 to March 2017. The inclusion criteria was that patient complaint was due to dental trauma. Data were tabulated indicating age and sex of the patient, cause, day, and tooth involved and the initial diagnosis of the dental trauma. Chi-square, Shapiro Wilk normality test and Mann-Whitney test were used for frequency analyses. A total of 117 dental records were analysed, 90 of these met the inclusion criteria. The age range of the sample was 5 to 60 years, and the average age was 14.3 years. Most injuries occurred in patients during the first and second decades of their life. Of the patients, $59.3 \%$ were men and 40.7 $\%$ were women. The most frequent dental traumas were complicated and uncomplicated crown fractures, followed by root fractures. In the majority of the cases analysed, only one tooth was affected, and the tooth most frequently traumatized was the right upper central incisor, followed by the left upper central incisor. The most frequent dental trauma of the cases treated at the Child and Adult Dental Traumatology Clinic, Faculty of Dentistry, Universidad de Chile, Santiago, between 2012 and 2017 were crown fractures.

KEY WORDS: traumatic dental injury, retrospective study, tooth fractures, epidemiology.

\section{INTRODUCTION}

The prevalence of traumatic dental injuries (TDI) is high, with approximately one third of all preschool children, one fourth of schoolchildren and one third of adults affected by them (Glendor, 2008). Most TDI's affect anterior teeth, these injuries have diverse consequences, including dietary restrictions, aesthetic changes, phonetic difficulties and quite often a psychological impact (Soriano et al., 2007; Thelen et al., 2010). Early treatment of TDI is fundamental, not only for correct diagnosis, but also to provide an adequate treatment plan, that will have an important repercussion on the prognosis of the affected teeth (Bakland \& Andreasen, 2004).
In Chile, similar to other countries, the prevalence is considerable (Onetto et al., 1994; Diaz et al., 2010; Castro Brezzo \& Dreyer Arroyo, 2012) and since 2007 its emergency treatment is included in the Explicit Health Guarantees (GES Program) for all the population affiliated to the public system through the National Health Fund (FONASA) and the private system through Health Care Institutions (ISAPRES) (Minsal, 2011). Nevertheless, there are large gaps related to the guarantees of financial protection and/or quality of the treatments performed (Velásquez et al., 2014).

\footnotetext{
${ }^{1}$ Department of Paediatric Dentistry, Faculty of Dentistry, Universidad de Chile, Santiago, Chile.

${ }^{2}$ Child and Adult Dental Traumatology Clinic, Faculty of Dentistry, Universidad de Chile, Santiago, Chile.

${ }^{3}$ EDF, Toltén, Chile.

${ }^{4}$ Department of Conservative Dentistry, Faculty of Dentistry, Universidad de Chile, Santiago, Chile.

${ }^{5}$ Department of Restorative Dentistry, Faculty of Dentistry, Universidad de Chile, Santiago, Chile.
} 
The Child and Adult Dental Traumatology Clinic, Faculty of Dentistry, Universidad de Chile, Santiago, Chile provides dental care for patients affected by TDIs. However, it is not part of the network of GES Program providers, therefore it works as a private practice provider. The aim of the present retrospective study was to analyse data from records of patients seen at this clinic, between January 2012 and March 2017 regarding age, sex, cause and type of TDI, type and number of teeth affected, and day of the week when the dental trauma occurred.

\section{MATERIAL AND METHOD}

A retrospective study was performed, analysing the dental records of all patients seen at the Child and Adult Dental Traumatology Clinic, Faculty of Dentistry, Universidad de Chile, Santiago from January 2012 to March 2017. The dental records were examined for data acquisition, and records with incomplete information regarding diagnosis, affected teeth and cause of TDI were excluded, as well as cases not affected by dental trauma.

Data was tabulated considering age and sex of patient, cause of dental trauma, day of the week when trauma occurred, teeth involved and diagnosis. The causes of dental trauma were classified in five categories: Traffic accidents, falls, sports activities, fights and striking objects. The diagnoses were categorized according to the classification of the International Association of Dental Trauma.

Data analysis included descriptive statistics of frequency distribution. In addition, chi-square test for frequency analysis according to sex was performed and Shapiro Wilk normality tests and MannWhitney test for non-parametric data for associations using SPSS Statistics v.21.0 (SPSS Inc. Chicago-IL-USA). The significance level was set at $5 \%$.

\section{RESULTS}

Table I. Causes of dental trauma according to patient or tutor statement, registered in dental records of patients seen at the Child and Adult Dental Traumatology Clinic, Faculty of Dentistry, Universidad de Chile, Santiago from 2012-2017.

\begin{tabular}{lccc} 
Cause & Female & Male & $\mathrm{n}$ \\
\hline Traffic accident & 0 & 1 & 1 \\
Falls & 21 & 30 & 51 \\
Sports activities & 5 & 9 & 14 \\
Fight & 0 & 2 & 2 \\
Striking object & 10 & 12 & 22 \\
Total & 36 & 54 & 90 \\
\hline
\end{tabular}

Frequency of TDIs according to the day of the week when occurred

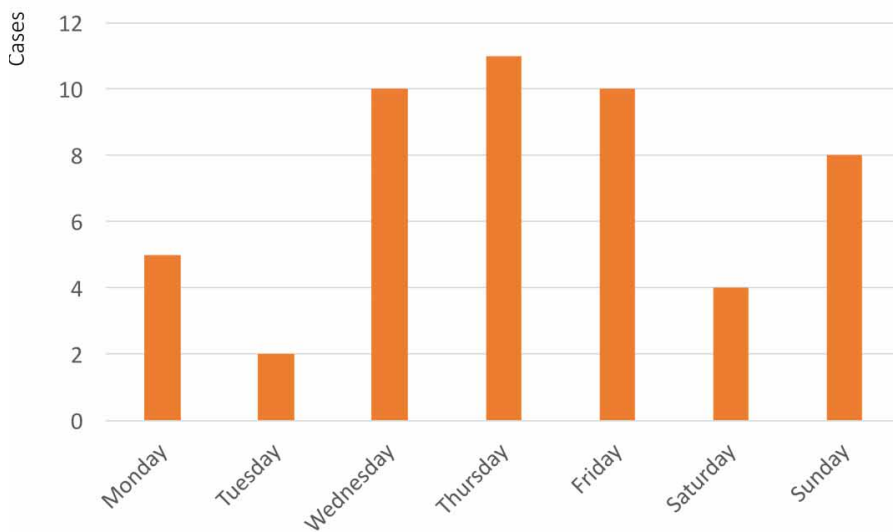

Fig. 1. Frequency of dental trauma according to the day of the week when occurred of patients seen at the Child and Adult Dental Traumatology Clinic, Faculty of Dentistry, Universidad de Chile, Santiago from 2012-2017.

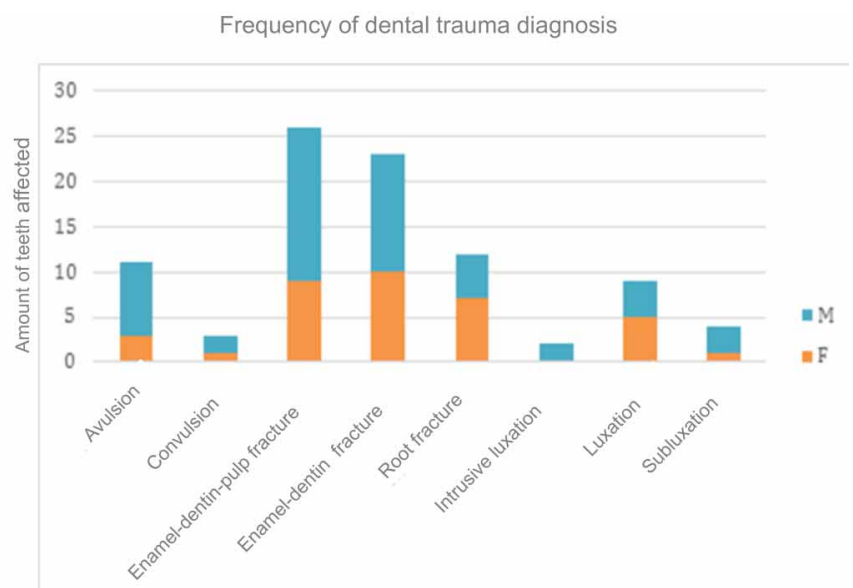

Fig. 2. Frequency of TDIs according to the type of teeth affected (the tooth most severely affected was consigned). 
One hundred and seventeen dental records were analysed, only 90 were included in the study ( 23 had non-dental trauma cause and 4 had incomplete dental records). The age range of the patients included in the study was from 5 to 60 years old, with an average of 14.3 years.

Of the 90 patients, 54 were males $(59.3$ $\%$ ) and 36 females (40.7\%). In most of the cases only one tooth was affected by TDI (57.8 $\%)$. According to sex, the mean number of teeth affected in females was 1.66 and males 1.57 . The sex difference in the number of teeth affected was not statistically significant $(p=0.98)$.

Table I describes the cause of the dental trauma according to statement of patients or tutor registered in the dental records. The most frequent causes were accidental falls (56.7 \%), followed by striking objects $(24.4 \%)$. Out of the analysed records, only 50 had recorded the day of the week when the injury occurred. Figure 1 shows the frequency of TDI according to the day of the week when happened. Most of the cases occurred during weekdays, Thursdays (22\%), Wednesdays (20\%) and Fridays $(20 \%)$. Figure 2 shows the frequencies according to the type of teeth affected (the tooth most severely affected was consigned). In all cases the affected teeth were incisors, and the tooth most frequently affected was upper right central incisor $(42.4 \%)$, followed by upper left central incisor (31.4\%).

Frequency of dental trauma diagnoses of patients seen at the Child and Adult Dental Traumatology Clinic, Faculty of Dentistry, Universidad de Chile, Santiago from 2012-2017 are shown in Fig.3. The most prevalent diagnoses were complicated $(28.9 \%)$ and not complicated coronal fractures $(25.6 \%)$, followed by root fractures (13.3\%), and the ages of patients are displayed in Fig. 4.

\section{DISCUSSION}

The present is a retrospective study that aimed to analyse the dental records of patients seen at the Child and Adult Dental Traumatology Clinic, Faculty of Dentistry, Uni-

\section{Frequency of teeth affected}

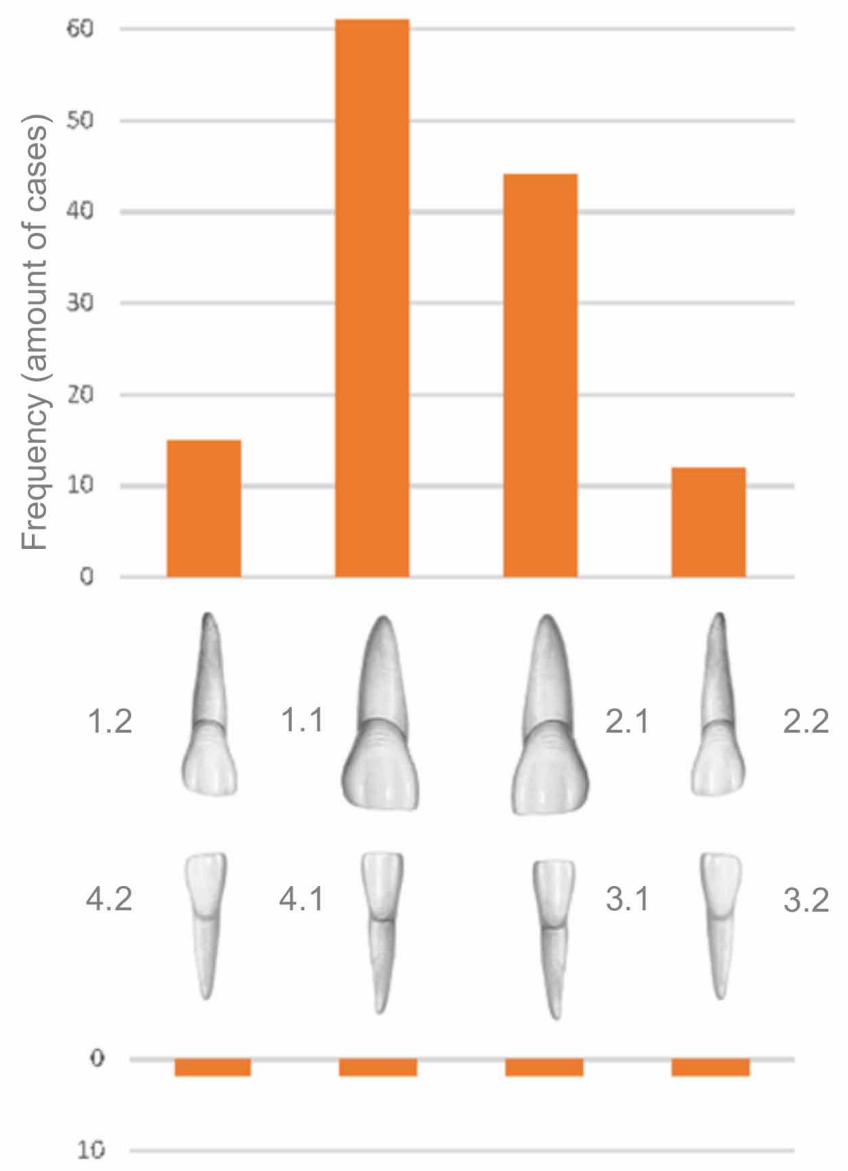

Fig. 3. Frequency of dental trauma diagnoses of patients seen at the Child and Adult Dental Traumatology Clinic, Faculty of Dentistry, Universidad de Chile, Santiago from 2012-2017.

Frequency of dental trauma according to age

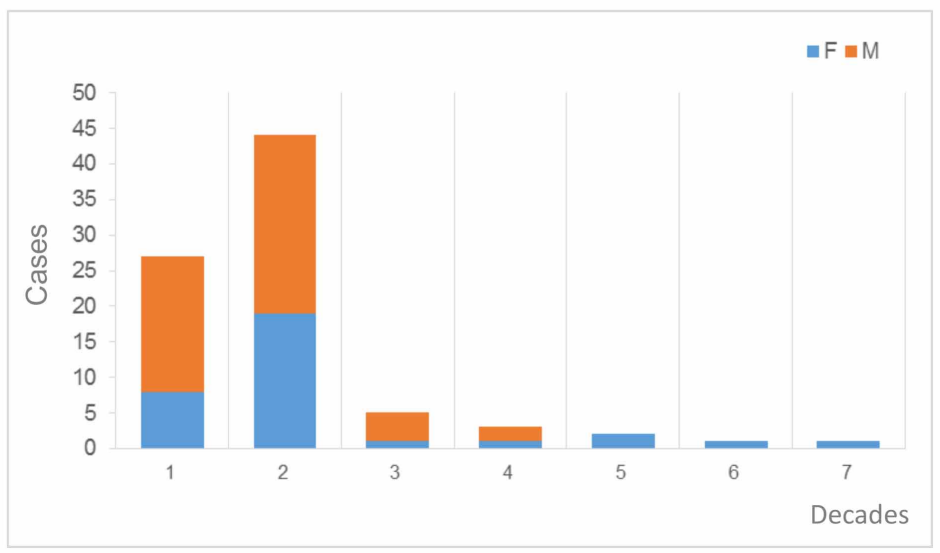

Fig. 4. Frequency of dental trauma according to age of patients seen at the Child and Adult Dental Traumatology Clinic, Faculty of Dentistry, Universidad de Chile, Santiago from 2012-2017. (F: female, M: male). 
versidad de Chile, Santiago. The World Health Organization (WHO) advocates conducting national epidemiological studies to monitor oral health status in specific age-groups (World Health Organization, 2013), however to overcome financial, logistical and additional difficulties in other types of studies, retrospective studies are frequently preferred. Therefore, similar to the present study there are several retrospective reports in dental trauma, which main disadvantage is that they are limited to specific subpopulations (Bastone et al., 2000).

The Child and Adult Dental Traumatology Clinic is based at the Faculty of Dentistry of the Universidad de Chile located, in the Independencia commune of the Metropolitan Region in Chile. According to data from CASEN Survey (National Socioeconomic Characterization Survey) 2011 in this commune $90 \%$ of the population is affiliated to FONASA, and $5.8 \%$ to ISAPRES. Although, urgent care is included in the GES program, the lack of knowledge of this coverage and the scare availability of Dental Care Emergency Centres open 24/7 (Velásquez et al.) are the likely reasons for patients to seek care in other centres, such as the Child and Adult Dental Traumatology Clinic, Faculty of Dentistry, Universidad de Chile, which are not part of the GES Program providers. In addition, large gaps related to the financial guarantees and/or quality of treatments performed in the GES Program care centres have been reported (Velásquez et al.). The Child and Adult Dental Traumatology Clinic, Universidad de Chile not only provides dental care for emergency TDIs, but also long term, and follow-up treatment.

The most prevalent type of dental trauma found in this study was crown fracture (including enameldentin fracture with and without pulp exposure). Crown fractures are the most prevalent type of TDI in permanent dentition (Diangelis et al., 2012), however the exact prevalence varies with the location and age range studied (Ravishankar et al., 2010; Tapias et al., 2003; Tovo et al., 2004). In this study, $28.9 \%$ were complicated enamel/dentin fracture, $25.6 \%$ were noncomplicated enamel/dentin fractures. Conversely, most of the studies described a majority of non-complicated enamel/dentin fracture (Al-Majed et al., 2001; Bastone et al.). This difference could be explained because the Child and Adult Dental Traumatology Clinic does not work as GES Program provider, and the actual prevalence of the types of TDIs that attend this centre might vary considerable, compared to the entire population prevalence. Similarly, variation in the number of patients that need attention due to TDIs has also changed in public hospitals, after the GES program was installed (Velásquez et al.).

In this study, most of the patients treated at the Child and Adult Dental Traumatology Clinic were in the first and second decade of age. These results are in agreement with several other reports studying different populations (Bastone et al.; Castro Brezzo \& Dreyer Arroyo; Diaz et al.). In 2000, a review carried out by Bastone et al. reports a peak between 9-15 years when the frequency of TDIs increases. Similarly, it is recognized that there is tendency of TDIs to occur when the body is growing and developing, therefore mainly during childhood and adolescence (Glendor).

Regarding sex, in this study $59.3 \%$ of the attended cases were males and $40.7 \%$ were females. Other studies have found a significant difference between the prevalence of TDIs according to sex, (Bastone et al.; Caldas \& Burgos, 2001; Castro Brezzo \& Dreyer Arroyo; Diaz et al.) stating even that males experience TDls at least twice as often as females (Glendor). However, a question has been raised whether this tendency will be maintained or not (Glendor). A decrease in sex difference has been reported and attributed to current behavioural changes, with females showing greater interest and involvement in high-risk activities and sports (Glendor; Rocha \& Cardoso, 2001; Traebert et al., 2003).

The most frequently affected teeth in the present study were incisors, with upper central incisor being the most prevalent one. Upper incisors tend to be at greater risk, because its position is normally more protruded than lower incisors. In most of the cases, a single tooth was affected, and the number of teeth affected was not related to sex. A review in the subject concluded that TDIs usually affect a single tooth, however there are specific types of trauma (sports, violence and traffic accident) that affect multiple teeth (Glendor). The aetiology of the cases considered in the current study was mainly due to falls and striking objects. The Child and Adult Dental Traumatology Clinic, Universidad de Chile, is not part of the public health system and it is not based at a hospital, therefore more severe traumas that affect not only the oral cavity tissues are probably seen at other facilities.

There are few studies aiming to assess the day of the week when TDIs are more prevalent. The present study showed higher occurrence during weekdays, with more than $60 \%$ occurrence from Thursday to Friday. In contrast, a study of a Public Hospital in the 
VÉLIZ, A.; CATALÁN, B.; RIOSECO, C.; JEREZ, P.; LATAPIAT, A.; MATAMOROS, D. \& CORRAL, C. Retrospective study of traumatic dental injuries of patients treated at a dental trauma clinic in Santiago, Chile. Int. J. Odontostomat., 11(4):405-410, 2017.

Metropolitan Region did not show a tendency for a certain day (Mella et al., 2014).

Traumatic injuries are common at young ages, therefore the treatment including follow up might last several years. In addition, the majority of TDIs involve anterior teeth, therefore, they are commonly associated to aesthetic, phonetic, and psychological consequences. Further investigations are needed, with representative populations using standardized trauma classifications to understand the complexities of dental trauma epidemiology and help to determine adequate strategies to prevent and provide good treatment.

\section{CONCLUSIONS}

The most frequent dental trauma of the cases treated at the Child and Adult Dental Traumatology Clinic between 2012 and 2017 were crown fractures, in patients who are in the first and second decade of life.

VÉLIZ, A.; CATALÁN, B.; RIOSECO, C.; JEREZ, P.; LATAPIAT, A.; MATAMOROS, D. \& CORRAL, C. Estudio retrospectivo de casos atendidos en clínica de traumatología dentoalveolar en Santiago, Chile. Int. J. Odontostomat., 11(4):405-410, 2017.

RESUMEN: El objetivo fue realizar un estudio retrospectivo de los casos que acuden a la clínica de Traumatología Dentoalveolar (TDA) Pediátrica y del Adulto de la Clínica de Odontología de la Universidad de Chile. Se realizó un estudio retrospectivo analizando las fichas de pacientes atendidos en la Clínica de TDA de la Facultad de Odontología, Universidad de Chile desde enero 2012 hasta marzo 2017. El criterio de inclusión fue motivo de consulta por traumatismo dentoalveolar inmediato. Se tabularon datos consignando sexo y edad del paciente, causa, día, diente involucrado y diagnóstico inicial del TDA. Para los análisis de frecuencia se utilizó Chi-cuadrado, el test de normalidad de Shapiro Wilk y test de Mann-Whitney. Se analizaron un total de 117 fichas, donde 90 cumplieron con los criterios de inclusión. El rango de edad de la muestra fue de 5 a 60 años, con un promedio de 14,3 años. Siendo la primera y la segunda década de vida donde ocurren con mayor frecuencia los traumatismos. El $59,3 \%$ eran hombres y $40,7 \%$ mujeres. El TDA más frecuente fueron las fracturas coronarias complicadas y no complicadas, seguido por fracturas radiculares. En la mayoría de los casos analizados sólo un diente se encontraba afectado. El diente más frecuentemente traumatizado fue el incisivo central superior derecho, seguido por el izquierdo. Las causas más frecuentes de trauma- tismo fueron por caída y golpe. De los casos atendidos en la clínica de TDA de la Universidad de Chile entre 2012 y 2017 el traumatismo más frecuente es la fractura coronaria.

PALABRAS CLAVE: traumatismo dentoalveolar, estudio retrospective, fractura dental, epidemiologia.

\section{REFERENCES}

Al-Majed, I.; Murray, J. J. \& Maguire, A. Prevalence of dental trauma in 5-6- and 12-14-year-old boys in Riyadh, Saudi Arabia. Dent. Traumatol., 17(4):153-8, 2001.

Bakland, L. K. \& Andreasen, J. O. Dental traumatology: essential diagnosis and treatment planning. Endod. Topic., 7:14-34, 2004.

Bastone, E. B.; Freer, T. J. \& McNamara, J. R. Epidemiology of dental trauma: a review of the literature. Aust. Dent. J., 45(1):2-9, 2000.

Caldas, A. F. Jr. \& Burgos, M. E. A retrospective study of traumatic dental injuries in a Brazilian dental trauma clinic. Dent. Traumatol., 17(6):250-3, 2001.

Castro Brezzo, P. F. \& Dreyer Arroyo, E. Prevalencia de traumatismos dentoalveolares en pacientes infantiles del complejo asistencial Dr. Sótero del Río. Rev. Clin. Periodoncia Implantol. Rehabil. Oral., 5(3):127-30, 2012.

Diangelis, A. J.; Andreasen, J. O.; Ebeleseder, K. A.; Kenny, D. J.; Trope, M.; Sigurdsson, A.; Andersson, L.; Bourguignon, C.; Flores, M. T.; Hicks, M. L.; Lenzi, A. R.; Malmgren, B.; Moule, A. J.; Pohl, Y.; Tsukiboshi, M. \& International Association of Dental Traumatology. International Association of Dental Traumatology guidelines for the management of traumatic dental injuries: 1 . Fractures and luxations of permanent teeth. Dent. Traumatol., 28(1):2-12, 2012.

Diaz, J. A.; Bustos, L.; Brandt, A. C. \& Fernandez, B. E. Dental injuries among children and adolescents aged 1-15 years attending to public hospital in Temuco, Chile. Dent. Traumatol., 26(3):254-61, 2010.

Glendor, U. Epidemiology of traumatic dental injuries--a 12 year review of the literature. Dent. Traumatol., 24(6):60311, 2008.

Mella, M. F.; Retamales, S. C. \& Perez, A. O. Prevalencia de las patologías odontopediátricas atendidas en el Servicio de Urgencia Odontológico del Hospital de Niños, Roberto del Río, durante el año 2013. Rev. Dent. Chile, 105(3):4-7, 2014.

Ministerio de Salud, Chile (Minsal). Guía Clínica Urgencias Odontológicas Ambulatorias. 2011.

Onetto, J. E.; Flores, M. T. \& Garbarino, M. L. Dental trauma in children and adolescents in Valparaiso, Chile. Endod. Dent. Traumatol., 10(5):223-7, 1994.

Ravishankar, T. L.; Kumar, M. A.; Ramesh, N. \& Chaitra, T. R. Prevalence of traumatic dental injuries to permanent incisors among 12-year-old school children in Davangere, South India. Chin. J. Dent. Res., 13(1):57-60, 2010.

Rocha, M. J. \& Cardoso, M. Traumatized permanent teeth in 
VÉLIZ, A.; CATALÁN, B.; RIOSECO, C.; JEREZ, P.; LATAPIAT, A.; MATAMOROS, D. \& CORRAL, C. Retrospective study of traumatic dental injuries of patients treated at a dental trauma clinic in Santiago, Chile. Int. J. Odontostomat., 11(4):405-410, 2017.

Brazilian children assisted at the Federal University of Santa Catarina, Brazil. Dent. Traumatol., 17(6):245-9, 2001.

Soriano, E. P.; Caldas Ade, F., Jr.; Diniz De Carvalho, M. V. \& Amorim Filho Hde, A. Prevalence and risk factors related to traumatic dental injuries in Brazilian schoolchildren. Dent. Traumatol., 23(4):232-40, 2007.

Tapias, M. A.; Jiménez-Garcia, R., Lamas, F. \& Gil, A. A. Prevalence of traumatic crown fractures to permanent incisors in a childhood population: Móstoles, Spain. Dent. Traumatol., 19(3):119-22, 2003.

Thelen, D. S. \& Bårdsen A. Traumatic dental injuries in an urban adolescent population in Tirana, Albania. Dent. Traumatol., 26(5):376-82, 2010.

Tovo, M. F.; dos Santos, P. R.; Kramer, P. F.; Feldens, C. A. \& Sari, G. T. Prevalence of crown fractures in 8-10 years old schoolchildren in Canoas, Brazil. Dent. Traumatol., 20(5):251-4, 2004.

Traebert, J.; Peres, M. A.; Blank, V.; Böell Rda S. \& Pietruza, J.A. Prevalence of traumatic dental injury and associated factors among 12-year-old school children in Florianopolis, Brazil. Dent. Traumatol., 19(1):15-8, 2003.

Velásquez, F.; Mancilla, C.; Niño, A. Y.; Tirreau, V.; CortésAraya, J.; Rojas, M. C.; Escobar, E.; Reyes-Court, D.; Calleja, S.; Ulloa-Marín, C. \& Sung-Hsieh, H. H. Patrones epidemiológicos del Trauma Dentoalveolar (Patología GES) en Pacientes Adultos atendidos en un centro de trauma de Chile durante 2 periodos. Int. J. Odontostomat, 8(2):191-9, 2014.

World Health Organization (WHO). Oral health surveys : basic methods. 5th edition. ed. Geneva: World Health Organization, 2013.
Corresponding author:

Camila Corral Nuñez

Department of Restorative Dentistry

Faculty of Dentistry

Universidad de Chile

Sergio Livingstone Pohlhammer 943

Independencia

Santiago

CHILE

E-mail: camila.corral@u.uchile.cl

Received: 07-08-2017

Accepted: 08-11-2017 